21. Schifter S. Circulating concentrations of calcitonin generelated peptide (CGRP) in normal man determined with a new, highly sensitive radioimmunoassay. Peptides 1991;12: 365-369.

22. Buzzi MG, Carter WB, Shimizu T, Heath H, Moskowitz MA. Dihydroergotamine and sumatriptan attenuate levels of CGRP in plasma in rat superior sagittal sinus during electrical stimulation of the trigeminal ganglion. Neuropharmacology 1991;30:1193-1200.

23. Levine JD, Fields HL, Basbaum AI. Peptides and the primary afferent nociceptor. J Neurosci 1993;13:2273-2286.

24. Morton CR, Hutchison WD. Morphine does not reduce the intraspinal release of calcitonin gene-related peptide in the cat. Neurosci Lett 1990;117:319-324.

25. Zaidi M, Bevis PJ, Abeyasekera G, et al. The origin of circulating calcitonin gene-related peptide in the rat. J Endocrinol 1986;110:185-190.

26. Wimalawansa SJ, MacIntyre I. Heterogeneity of plasma calcitonin gene-related peptide: partial characterisation of immunoreactive forms. Peptides 1988;9:407-410.

27. Goadsby PJ, Edvinsson L, Ekman R. Release of vasoactive peptides in the extracerebral circulation of humans and the cat during activation of the trigeminovascular system. Ann Neurol 1988;23:193-196.

28. Goadsby PJ, Edvinsson L. The trigeminovascular system and migraine: studies characterizing cerebrovascular and neuropeptide changes seen in humans and cats. Ann Neurol 1993; 33:48-56.

29. Gallai V, Sarchielli P, Floridi A, et al. Vasoactive peptide levels in the plasma of young migraine patients with and without aura assessed both interictally and ictally. Cephalalgia 1995; $15: 384-390$.

30. Ekins RP, Newman GB. Optimization of radioimmunoassay, protein binding and other saturation assay techniques. J Endocrinol 1973;58:xxi.

31. Bach FW, Langemark M, Ekman R, Rehfeld JF, Schifter S, Olesen J. Effect of sulpiride or paroxetine on cerebrospinal fluid neuropeptide concentrations in patients with chronic tension-type headache. Neuropeptides 1994;27:129-136.

32. Girgis SI, Macdonald DW, Stevenson JC, et al. Calcitonin gene-related peptide: potent vasodilator and major product of calcitonin gene. Lancet 1985;6:14-16.

\title{
Neuro/mages
}

\section{MR choroid plexus sign of iron overload}

R. Kira, MD, PhD, S. Ohga, MD, PhD, H. Takada, MD, PhD,

K. Gondo, MD, PhD, F. Mihara MD, PhD,

T. Hara, MD, PhD, Fukuoka, Japan

A 7-year-old boy with Diamond-Blackfan anemia was transfusion-dependent at age 4 , at which point hemochromatosis progressed. Laboratory studies showed the following: iron $292 \mu \mathrm{g} / \mathrm{dL}$ (normal, 70 to $190 \mu \mathrm{g} / \mathrm{dL}$ ), unsaturated iron binding capacity $29 \mu \mathrm{g} / \mathrm{dL}$ (normal, 130 to $370 \mu \mathrm{g} / \mathrm{dL}$ ), and ferritin $6403 \mathrm{ng} / \mathrm{mL}$ (normal, 26.0 to $250.0 \mathrm{ng} / \mathrm{mL}$ ). A brain MR study indicated the restricted accumulation of iron in the choroid plexus (figure). CT demonstrated no calcification on the choroid plexus. These findings are compatible with neuropathologic examination of a patient with hemochromatosis. ${ }^{1}$

According to the autoradiographic distribution in the adult rat brain, the choroid plexus showed the highest uptake level of ${ }^{59} \mathrm{Fe}$ from the blood. ${ }^{2}$ Thus, the choroid plexus might protect the brain from iron overloading through a buffering effect.

MRI, especially $\mathrm{T} 2 *$-weighted imaging, effectively detects iron overloading because of a striking reduction of $\mathrm{T} 2$ relaxation time. Further investigations by using $\mathrm{T} 2$ *- $^{-}$ weighted imaging are necessary in patients with various causes of iron overload including primary hemochromatosis and acute iron intoxication.

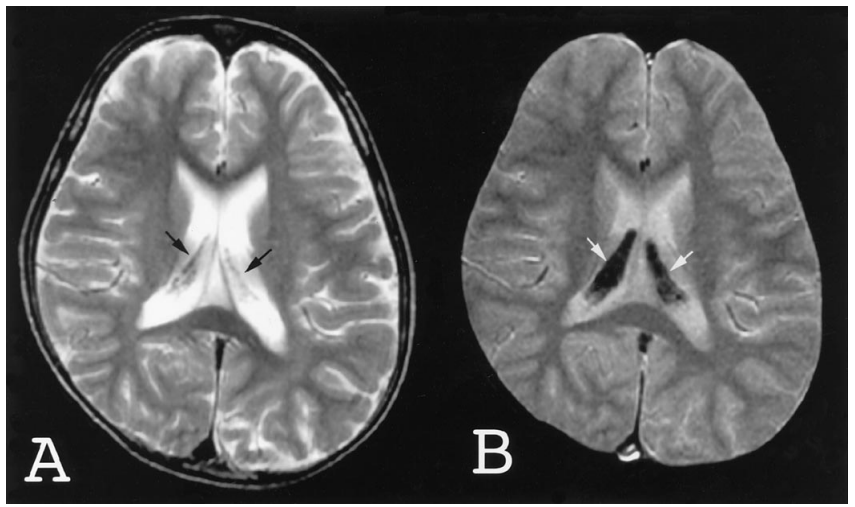

Figure. (A) Axial T2-weighted MRI shows decreased signal intensity over the bilateral choroid plexus (arrows). (B) A corresponding $T 2 *$-weighted image reveals more decreased and widespread signal intensity (arrows). The choroid plexus appeared normal on T1-weighted imaging and CT scanning.

\section{References}

1. Dwork AJ. Effects of diet and development upon the uptake and distribution of cerebral iron. J Neurol Sci 1995;134(suppl): $45-51$.

2. Morris CM, Keith AB, Edwardson JA, Pullen RG. Uptake and distribution of iron and transferrin in the adult rat brain. J Neurochem 1992;59:300-306. 


\section{Neurology}

\section{MR choroid plexus sign of iron overload \\ Neurology 2000;55;1340 \\ DOI 10.1212/WNL.55.9.1340}

This information is current as of November 14, 2000

\section{Updated Information \&}

Services

Permissions \& Licensing

Reprints including high resolution figures, can be found at: http://n.neurology.org/content/55/9/1340.full

Information about reproducing this article in parts (figures,tables) or in its entirety can be found online at:

http://www.neurology.org/about/about_the_journal\#permissions

Information about ordering reprints can be found online:

http://n.neurology.org/subscribers/advertise

Neurology ${ }^{\circledR}$ is the official journal of the American Academy of Neurology. Published continuously since 1951, it is now a weekly with 48 issues per year. Copyright . All rights reserved. Print ISSN: 0028-3878. Online ISSN: 1526-632X.

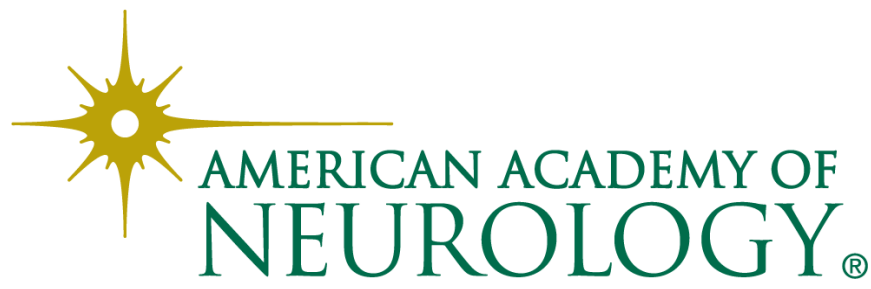

